\title{
STUDI WINDOW-TO-WALL RATIO PADA KANTOR PEMERINTAH DI JAKARTA SELATAN
}

\section{WINDOW-TO-WALL RATIO STUDY IN GOVERNMENT OFFICES IN SOUTH JAKARTA}

\author{
Melisa Imam Dwiana ${ }^{1}$, Agus Budi Purnomo², Nuzuliar Rahmah ${ }^{3}$ \\ Universitas Trisakti, \\ 1imammelisa@yahoo.co.id, ${ }^{2}$ agusbp@trisakti.ac.id, ${ }^{3}$ nuzuliar@trisakti.ac.id
}

\begin{abstract}
Abstrak : Kantor pemerintah merupakan bangunan yang diharapkan dapat menjadi contoh sebagai bangunan hemat energi yang baik. Banyak usaha yang dapat dilakukan untuk menghemat energi, salah satunya memperhatikan desain fasade. Jendela sebagai bukaan pada fasade dapat diatur sedemikian rupa sehingga panas matahari tidak membuat peningkatan energi untuk mendinginkan ruangan sekaligus mengurangi penggunaan lampu pada siang hari. Salah satu aspek yang dapat digunakan untuk menilai kinerja bukaan jendela adalah Window-to-Wall Ratio (WWR). Rasio diperoleh dengan membagi total luas bukaan pada dinding yang menggunakan kaca dengan luas permukaan keseluruhan bidang selubung bangunan. Tujuan dari penelitian ini adalah mempelajari nilai WWR dari bangunan kantor pemerintahan yang ada di Jakarta Selatan. Penelitian ini menggunakan tampak bangunan dari 20 gedung kantor pemerintahan di Jakarta Selatan sebagai kasus studi. Hasil penelitian berupa nilai rata rata WWR kantor pemerintahan yang nantinya dibandingkan dengan rata-rata WWR kantor sejenis dari literatur lain. Dari hasil penelitian, diperoleh rata rata nilai WWR sama dengan 24.6\%, yang mana masih berada di rentang WWR dalam penelitian lain. Kata kunci : Hemat Energi, Selubung Bangunan, Kantor Pemerintah, Window-to-Wall Ratio (WWR)
\end{abstract}

Abstract : Government offices are buildings that are expected to be a good example of energy-efficient buildings. Many efforts can be done to save energy, one of them is to pay attention to the design of the facade. Windows as openings in the facade can be arranged so that the sun's heat does not result in an increase of energy to cool the room also reducing the use of lights during the day. One od the aspect that can be used to assess window opening performance is Window-to-Wall Ratio (WWR). The ratio is obtained by dividing the total opening area of the wall using glass by the total surface area of the building envelope. The purpose of this research is to study the value of WWR from government office buildings in South Jakarta. This study use front elevation of 20 government office buildings in South Jakarta as a case study. The results of this study are the average WWR value of government offices which were later compared to the average $W W R$ of similar offices from other literature. From the results of the study, an average WWR value of 24.6\% was obtained, which is still in the range of WWR in other studies.

Keywords : Energy Saving, Building Envelope, Government Office, Window-to-Wall Ratio (WWR)

\section{PENDAHULUAN}

Jakarta Selatan merupakan wilayah yang banyak terdapat gedung perkantoran dibanding wilayah lainnya di Jakarta. Maka dari itu, diperlukan perhatian lebih saat proses merancang kantor untuk dapat menghemat energi secara masif. Ruangan kantor yang nyaman secara visual dipenuhi oleh bukaan pada dinding, yang mana mempengaruhi radiasi matahari yang masuk dan cahaya alami yang diterima di dalam ruangan selama siang hari (Alhagla, 2019). Pencahayaan alami menggunakan cahaya dari matahari untuk mengurangi pengunaan listrik untuk penerangan pada siang hari. Biasanya bukaan pada dinding berfungsi sebagai jendela. Jendela ini dipengaruhi oleh banyak variabel yang mempengaruhi desain, seperti rasio bukaan jendela terhadap dinding atau Window-to-Wall Ratio (WWR) dan jenis alat peneduh atau shading devices (Chou, 2004). 
Berdasarkan serangkaian prinsip arsitektur modern yang dikembangkan oleh Le Corbusier, bukaan pada dinding atau jendela memiliki tingkat kepentingan yang tinggi pada bangunan, karena bukaan pada dinding ini terlihat seperti bingkai. (Dehghan, 2019). Le Corbusier menekankan perancangan bukaan di dinding pada bangunan seolah olah ia melihat bingkai foto, menangkap pemandangan yang indah disekitar bangunan yang ingin ia perlihatkan kepada pengguna bangunan. Setelah merancang bukaan, alat peneduh untuk bukaan tersebut ditentukan untuk memperoleh tampilan yang diinginkan. Maka dari itu, dapat dikatakan bahwa Le Corbusier menganggap bentuk primer bangunan ditentukan oleh bukaan pada dinding sedangkan alat peneduh memberikan bentuk sekunder pada bangunan. Sudah sewajarnya jika diawal proses perancangan bangunan, arsitek lebih memperhatikan bukaan pada dinding dibandingkan alat peneduh. Sebagai aliran arsitektur yang menekankan elemen jendela pada perancangan bangunan, jendela memiliki banyak makna. Sejak aliran ini menganggap ornament adalah sebuah kejahatan yang harus dihindari, maka sebagai pengganti ornament yang berfungsi untuk mempercantik bangunan, digunakan jendela yang mana merupakan elemen penting yang melekat pada bangunan. Aliran Arsitektur Modern juga menganggap bukaan pada dinding atau jendela ini sebagai elemen bangunan yang menyimbolkan kebebasan (Ichikawa, 2018).

Dalam awal proses perancangan, ada banyak peluang untuk membuat keputusan terkait estetika, mulai dari penentuan bukaan pada dinding. Sejak awal proses merancang, bukaan pada dinding sudah menjadi dasar pertimbangan bagi arsitek (Gillem, 2016). Ini dikarenakan banyak hal yang dipengaruhi oleh bukaan pada dinding. Menurut SNI 036389-2000, bukaan pada dinding yang disebut sebagai Window-to-Wall Ratio (WWR) mempengaruhi komponen dasar Overal Thermal Transfer Value (OTTV). Overal Thermal Transfer Value atau OTTV adalah nilai perpindahan panas dari luar ke dalam gedung melalui selubung bangunan. Komponen OTTV ada 3 hal, yakni komponen konduksi melewati dinding, komponen konduksi melewati bukaan dan serta komponen radiasi dari matahari. Ketiga komponen ini semua berdasarkan SNI 03-6389-2000 dipengaruhi oleh besarnya nilai rasio luas bukaan dinding terhadap luas bidang keseluruhan. Ini menunjukkan betapa pentingnya Window-to-Wall Ratio (WWR) pada awal proses perancangan. Oleh karena itu, fokus dari penelitian ini adalah rasio bukaan jendela terhadap dinding, terutama pada bangunan kantor pemerintahan.

Menurut penelitian yang dilakukan Shaeri dkk (2019), menentukan Window-to-Wall Ratio yang tepat tergantung pada lokasi, orientasi, dan jenis bangunan tersebut. Dalam penelitian mereka ini secara teknis diawali dengan menghitung besar energi yang digunakan dan pencahayaan alami yang dibutuhkan bangunan tersebut. Penentuan WWR pada penelitian ini dilakukan dengan optimasi kuantitatif. Akan tetapi, optimasi kuantitatif bukanlah suatu cara pikir yang biasa digunakan oleh arsitek. Menurut Maduka (2019), arsitek terbiasa dengan cara berpikir yang eklektik. Eklektisme dalam arsitektur merupakan peminjaman ide dan elemen secara selektif yang dianggap sebagai elemen estetika. Ini menggambarkan bagaimana arsitek berpikir, memproses dan mempelajari dari sebuah desain (Lawson, 2003). Meski begitu, intensi arsitek dalam merancang bangunan tidak sepenuhnya ekletik (Norberg-Schulz, 1966). Arsitek mengambil material secara selektif yang ada pada desain yang sudah ada, menerapkan material tersebut pada desainnya, dimana material yang diambil dan diterapkan pada desain tidak sepenuhnya terkait faktor estetika. Material yang diambil juga mempertimbangkan efek yang diakibatkan dari faktor sosial, psikologis, budaya dan lain-lain. 
Maka dari itu, penelitian ini bertujuan untuk menentukan nilai WWR yang tepat dengan melakukan studi bukaan jendela pada desain selubung bangunan kantor pemerintahan yang ada. Objek studi dalam penelitian ini adalah 20 kantor pemerintahan yang berlokasi di Jakarta Selatan. Hasil penelitian ini berupa nilai rata rata rasio bukaan jendela terhadap dinding yang nantinya akan dibandingkan dengan literatur terkait yang membahas hal yang sama. Rata rata nilai WWR dari bangunan-bangunan kantor pemerintahan tersebut nantinya bisa dijadikan dasar perancangan dalam mendesain selubung bangunan kantor pemerintahan yang baik.

\section{METODE PENELITIAN}

Penelitian ini melaporkan hasil nilai rata rata WWR untuk jenis kantor pemerintahan.. Data objek bangunan yang dipakai pada penelitian ini diperoleh dari search engine Google Maps untuk mendeteksi lokasi dan Google Image serta 3D WareHouse Sketchup untuk mendapatkan gambar tampak depan. Dari sekian banyak bangunan kantor pemerintahan yang ada di Jakarta Selatan yang awalnya diidentifikasi oleh penulis, 20 bangunan kantor pemerintahan dipilih sebagai objek/kasus studi. Bangunan yang dipilih merupakan bangunan kantor pemerintahan yang memiliki foto tampak depan bangunan yang jelas sehingga dapat dijadikan acuan untuk menghitung nilai WWR.

Rumus yang digunakan untuk menghitung nilai rasio bukaan dinding menggunakan rumus yang dipakai dalam penelitian Chaerani. Menurut Chaerani (2017), rumus yang dapat digunakan untuk menghitung WWR bidang terpilih dari masing-masing bangunan adalah:

$$
\text { WWR } 1 \text { bidang }=\frac{\text { Afl bidang }}{\text { Aw1 bidang }}
$$

Af 1bidang: Luas jendela keseluruhan pada satu bidang Aw 1bidang: Luas permukaan keseluruhan satu bidang

Foto tampak bangunan yang telah dicari tersebut kemudian dikumpulkan dan diarsir bagian mana pada tampak bangunan yang merupakan bukaan pada dinding atau jendela. Untuk menghitung luas dinding keseluruhan dan luas bukaan pada tampak depan bangunan yang dijadikan objek/kasus studi, dibuat garis bantu berupa grid pada foto
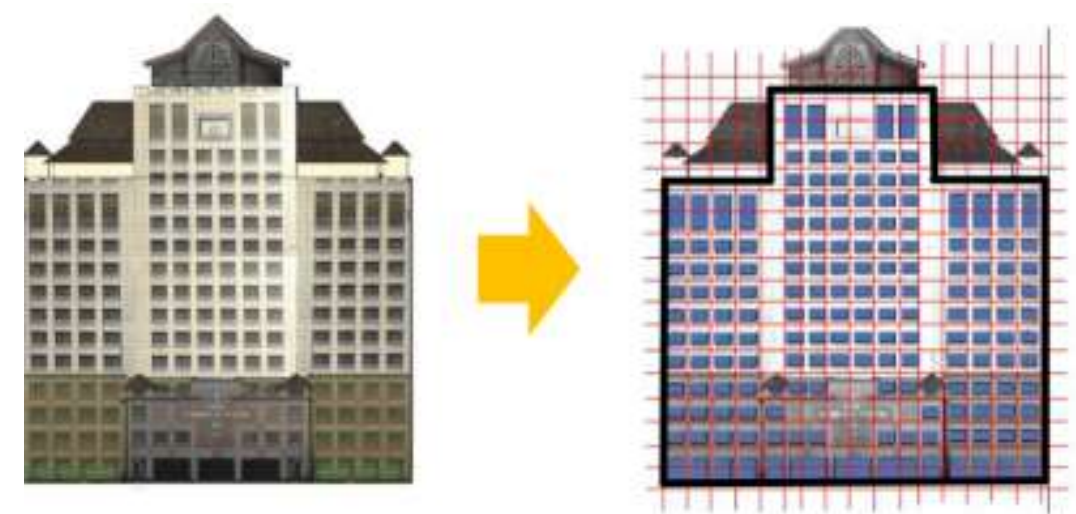

tampak bangunan tersebut. Dengan bantuan garis bantu ini, WWR tiap kasus diukur.

Gambar 2. Proses menghitung dengan meletakkan grid pada tampak depan bangunan 
Pada tahap ini, tidak semua bagian yang menggunakan material kaca dihitung sebagai jendela. Bagian yang dianggap dan dihitung sebagai Af 1bidang adalah hanya bidang kaca yang tidak dihalangi elemen struktural yang dianggap sebagai jendela sedangkan bagian Aw 1bidang adalah luas seluruh permukaan dinding pada tampak. Pada gambar 2, Af 1bidang ditunjukkan oleh bentuk warna biru sedangkan Aw lbidang ditunjukkan bentuk yang digarisi hitam tebal. Luas diperoleh dengan menggunakan persamaan matematika.

Data pengukuran yang telah diperoleh tersebut diolah dengan ditempatkan dalam bentuk tabel yang berisikan data sesuai dengan kebutuhan analisis menggunakan software Microsoft Excel. Hasil olahan data tersebut disajikan berbentuk diagram berisi WWR setiap kasus studi, beserta rata-rata WWR dari keseluruhan. Rata-rata WWR ini dikomparasikan dengan literatur yang memuat penelitian nilai rasio bukaan terhadap dinding pada kantor pemerintahan. Apabila rata rata nilai rasio dalam penelitian ini cocok dengan nilai rasio yang disarankan dalam literatur tersebut, maka dapat digunakan sebagai acuan nilai WWR untuk perancangan kantor pemerintahan.

\section{HASIL DAN TEMUAN}

Analisis nilai WWR dilakukan dengan memperkirakan luas bukaan pada dinding dengan catatan bahwa tidak semua permukaan yang menggunakan material kaca dianggap sebagai bukaan jendela. Hanya permukaan yang tidak dihalangi elemen struktur diblakang kaca yang dianggap sebagai bukaan pada dinding. Pada perhitungan WWR dari 20 kantor pemerintahan di Jakarta Selatan menghasilkan nilai rata rata WWR sebesar 24.6\%, dengan rentang antara $10 \%$ sampai dengan $45 \%$. Jumlah bangunan dengan nilai $10 \%$ sampai dengan $20 \%$ adalah 7 bangunan, nilai rasio $21 \%$ sampai dengan $30 \%$ adalah 10 bangunan, nilai rasio $31 \%$ sampai dengan $40 \%$ adalah 2 bangunan, nilai rasio $41 \%$ sampai dengan 45\% adalah 1 bangunan. Bangunan kantor pemerintah didominasi memiliki nilai WWR sebesar $21 \%$ sampai dengan $30 \%$, dengan jumlah 10 bangunan, maka tidak heran jika rata rata berada di range ini, yakni $24.6 \%$.

Pada penelitian ini, kantor pemerintahan yang memiliki nilai rasio bukaan jendela terhadap dinding yang mendekati rata-rata adalah kasus studi no 11 , dengan persentase $23 \%$. Persentase ini berarti bahwa pada tampak depan bangunan kasus studi no 11, hanya 23\% dari luas permukaan seluruhnya digunakan sebagai bukaan jendela. Foto tampak depan bangunan kasus studi no 11 dapat dilihat pada gambar 3 .

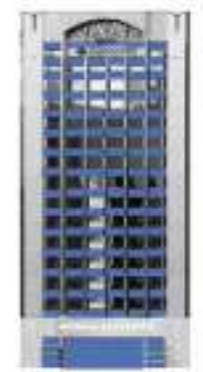

Gambar 3. Kasus Studi Kantor Pemerintahan no. 11. Sumber: 3D WareHouse Sketchup 
Dari 20 kantor pemerintahan yang diteliti peneliti, kantor pemerintahan yang memiliki nilai rasio bukaan jendela terhadap dinding terkecil adalah kasus studi no 5, dengan persentase $10 \%$. Persentase ini berarti bahwa pada tampak depan bangunan kasus studi no 5 , hanya $10 \%$ dari luas permukaan seluruhnya merupakan bukaan dinding. Persentase yang sangat rendah ini diakibatkan fasad kantor pemerintahan ini mengalami modifikasi. Pada fasad bangunan, ditambah kembali lapisan komposit yang nyaris menutupi kaca gedung. Foto tampak depan bangunan kasus studi no 5 dapat dilihat pada gambar 4 .

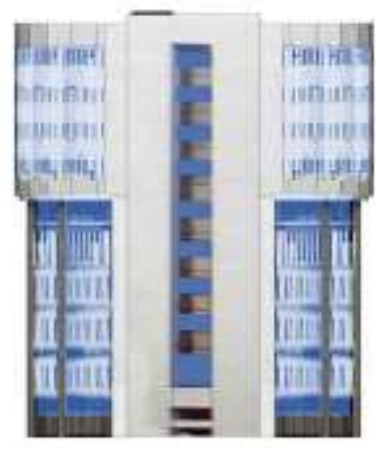

Gambar 4. Kasus Studi Kantor Pemerintahan no. 5.

Sumber: 3D WareHouse Sketchup

Untuk kantor pemerintahan yang memiliki nilai rasio bukaan jendela terhadap dinding terbesar adalah kasus studi no 1, dengan persentase $45 \%$. Persentase ini berarti bahwa pada tampak depan bangunan kasus studi no 1, bangunan ini menggunakan $45 \%$ dari keseluruhan luas permukaan tampak depan untuk bukaan dinding. Foto tampak depan bangunan kasus studi no 5 dapat dilihat pada gambar 5 .

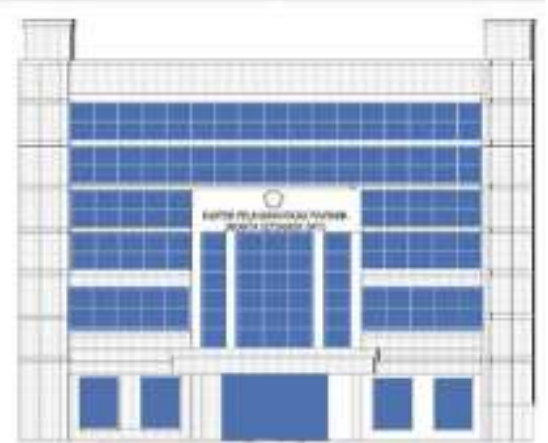

Gambar 5. Kasus Studi Kantor Pemerintahan no. 1.

Sumber: 3D WareHouse Sketchup

\section{DISKUSI DAN PEMBAHASAN}

Rata-rata dari WWR 20 kantor pemerintahan di Jakarta Selatan yg menjadi kasus penelitian ini adalah 24.6\%. Rasio rata rata ini berarti bahwa majoritas kantor pemerintahan yang ada di jakarta selatan menggunakan $24.6 \%$ dari keseluruhan luas permukaan tampak depan bangunannya untuk jendela. Dapat disimpulkan bahwa pada umumnya selubung bangunan kantor pemerintahan tidak didominasi oleh bukaan dinding yang berfungsi sebagai jendela. Hal ini merupakan dampak dari Peraturan Gubernur 
(Pergub) Nomor 38 Tahun 2012 tentang Bangunan Gedung Hijau yang lebih ketat untuk bangunan milik pemerintahan, salah satunya kantor pemerintahan. Ini diakibatkan harapan gubernur agar gedung pemerintahan dapat menjadi contoh yang baik dalam menerapkan peraturan ini, sehingga dapat diikuti oleh bangunan lainnya milik sektor swasta.

Untuk mengetahui apakah rata rata dari WWR 20 kantor pemerintahan di Jakarta Selatan ini dapat digunakan sebagai acuan, diperlukan komparasi terhadap literatur yang membahas rasio bukaan dinding kantor pemerintahan. Peneliti mencari 5 jurnal dengan bahasan yang sama mengenai WWR kantor pemerintahan yang tepat untuk digunakan sebagai pembanding. Setelah dikomparasi, barulah peneliti bisa menimbang apakah rata rata yang ditemukan peneliti bisa dijadikan acuan.

Rata-rata WWR hasil penelitian adalah $24.6 \%$, ternyata lebih besar daripada WWR bangunan kantor pemerintahan di Malaysia (Noor Laily, 2018). Noor Laily dkk (2018) dalam penelitiannya mengenai WWR kantor pemerintahan yang tepat untuk performa energi yang baik menyatakan bahwa rasio yang tepat adalah yang sesuai dengan standar ASHRAE 90.1-2007 dimana rata rata persentase bukaan pada dinding seluruh tampak adalah $20 \%$. Namun, jika dilihat pada penelitian yang dilakukan pada negara yang sama seperti peneliti lakukan, yakni Indonesia, Rata-rata WWR hasil penelitian masih masuk dalam rentang yang diperbolehkan (Wa Ode, 2015). Wa Ode dkk (2015) dalam penelitiannya membuktikan rasio yang tepat tergantung orientasi tampak bangunan dengan mengambil 2 kantor pemerintahan di Surabaya sebagai objek kasusnya. Penelitian ini membuktikan rasio yang tepat untuk bagian barat, barat laut dan barat daya yang merupakan sisi yang memperoleh sinar matahari terbesar adalah tidak lebih dari $20 \%$, sedangkan untuk orientasi mata angin lainnya diperbolehkan hingga 40\%. Di negara yang memiliki iklim yang berbeda, yakni China, ternyata memiliki nilai WWR yang lebih besar dibandingkan rata rata wwr yang ditemukan dalam penelitian ini. (Ding, 2017; Lee, 2015; Yan, 2017). Sebuah studi yang dilakukan Ding dkk (2017) pada 37 kantor pemerintahan di China yang memiliki iklim dingin menyatakan bahwa bukaan yang tepat pada dinding untuk hemat konsumsi energi berada pada rentang 30\% sampai 40\%. Lee dkk (2015) dalam penelitiannya mengenai potensi kantor pemerintahan di Shanghai dalam mencapai bangunan yang rendah energi menyatakan bahwa rasio yang tepat untuk kantor pemerinatahan dengan luas lebih dari $5000 \mathrm{~m}^{2}$ berada pada rentang di antara $50 \%$ sampai dengan 70\%. Masih di negara yang sama, Yan dkk (2017) menyatakan bahwa WWR yang tepat untuk kantor pemerintahan di China dibagi menjadi 2 tipe berdasarkan luas total lantai, yakni tipe A dengan luas total lantai kurang dari $20.000 \mathrm{~m}^{2}$ dan tipe B dengan luas total lantai lebih dari $20.000 \mathrm{~m}^{2}$. Untuk tipe A, WWR diperbolehkan lebih dari $50 \%$ hingga mencapai $70 \%$ sedangkan untuk tipe B disarankan untuk dibawah 50\%. Nilai dalam jurnal penelitian tersebut lebih besar dari pada WWR rata rata kantor pemerintahan di Jakarta Selatan yang diperoleh dalam penelitian ini. Maka dari itu dari kelima jurnal tersebut, dapat dinyatakan bahwa nilai WWR 24.6\% masih berada pada rentang yang diperbolehkan untuk kantor pemerintahan.

Meski begitu, penelitian ini masih banyak kelemahan dikarenakan tidak seperti pada kelima jurnal tersebut, peneliti tidak mengidentifikasi variabel lain yang mempengaruhi, seperti orientasi tampak bangunan seperti dalam penelitian yang dilakukan Wa Ode dkk (2015) dan luas total lantai bangunan pada penelitian yang dilakukan Lee dkk (2015) dan Yan dkk (2017). Hal ini diakibatkan keterbatasan dalam memperoleh data terkait kedua hal 
tersebut, dimana peneliti hanya bergantung pada model dan foto bangunan yang ada pada internet.

\section{KESIMPULAN}

Penelitian yang dilakukan ini menganalisa nilai WWR yang dapat digunakan pada kantor pemerintahan. Komparasi antara Nilai rata rata WWR hasil penelitian ini dengan nilai wwr yang disarankan pada literatur yang ada untuk mengevaluasi nilai rasio bukaan dinding yang dapat digunakan pada kantor pemerintahan. Pada literatur yang dipelajari peneliti, diketahui bahwa WWR adalah variabel yang sangat penting bagi perancangan selubung bangunan, terlebih untuk kantor pemerintahan dimana bangunan milik pemerintah diharuskan memliki desain yang hemat energi. Hal ini diakibatkan banyak hal yang dipengaruhi WWR yang berkaitan dengan konsumsi energi.

Dari penelitian ini, rata rata WWR kantor pemerintahan yang ada di Jakarta Selatan adalah 24,6\%. Rasio rata rata ini jika dibandingkan dengan jurnal penelitian yang membahas hal yang sama pada kantor sejenis masih berada pada rentang yang diperbolehkan. Dalam penelitian yang dilakukan di lokasi dengan iklim serupa, yakni surabaya (Wa Ode, 2015) dan Malaysia (Noor Laily, 2018). WWR yang disarankan berada pada rentang 20\%-40\% dengan syarat orientasi barat harus $20 \%$. untuk penelitian yang dilakukan di negara yang memiliki iklim yang berbeda, yakni China, WWR hasil penelitian ini jauh lebih kecil dibandingkan nilai yang disarankan (Ding, 2017; Lee, 2015; Yan, 2017). penelitian yang dilakukan di china ini menunjukan nilai yang diperbolehkan berada pada rentang 30-50\% untuk iklim dingin, dan 50\%-70\% untuk iklim sangat dingin.

Meski begitu, penetapan rata rata WWR dalam penelitian ini tidak memperhatikan orientasi selubung bangunan, dan total luas lantai kantor pemerintahan tersebut. Maka dari itu, rata rata ini hanya bisa membantu sebagai pertimbangan cepat bagi perancang saat merancang bangunan kantor pemerintahan. Diperlukan penelitian mendalam dengan memperhatikan variabel lain yang mempengaruhi seperti lokasi, orientasi, konsumsi energi dan total luas lantai, sehingga penelitian ini bisa lebih baik. Dengan memperhatikan variabel - variabel lain tersebut, hasil penelitian bisa digunakan untuk mengukur performa energi melalui perhitungan OTTV (Overal Thermal Transfer Value).

\section{UCAPAN TERIMA KASIH}

Seperti yang dinyatakan pada bagian diskusi dan pembahasan, penelitian ini masih banyak kekurangan. Walaupun begitu, peneliti ingin tetap mengucapkan ucapan terima kasih. Penyusunan paper penelitian ini tidak akan selesai tanpa bantuan dari banyak pihak. Ucapan terima kasih penulis ucapkan kepada Bapak Prof. Agus Budi Purnomo, Ph.D selaku pembimbing utama dan Ibu Ir. Nuzuliar Rahmah, MT selaku pembimbing pendamping yang telah membantu penulis sehingga artikel ini dapat terselesaikan. 


\section{DAFTAR PUSTAKA}

[1] Alhagla, K., Mansour, A., \& Elbassuoni, R., "Optimizing Windows For Enhancing Daylighting Performance And Energy Saving”, Alexandria Engineering Journal, Vol. 58, Issue 1, March (2019), pp 283-290. doi: https://doi.org/10.1016/j.aej.2019.01.004

[2] ASHRAE., Handbook: Fundamentals., American Society of Heating Refrigerating and Air Conditioning Engineers, (1993), Inc. Atlanta.

[3] Badan Standardisasi Nasional., Konservasi Energi Selubung Bangunan Pada Bangunan Gedung., SNI 03-6389-2000, (2000), Jakarta, Indonesia.

[4] Chaerani, R.D., Suprayogi \& Djunaedy, E., "OPTIMALISASI BUKAAN JENDELA UNTUK PENCAHAYAAN ALAMI DAN KONSUMSI ENERGI BANGUNAN", e-Proceedings of Engineering, Vol. 4 No.3, pp. 3936-3944, Bandung, Desember (2017), Telkom University, Bandung.

[5] Chou, CP., "The Performance of Daylighting with Shading Device in Architecture Design", Tamkang Journal of Science and Engineering, (2004), Vol. 7 No. 4, pp. 205-212.

[6] Dehghan, Y., "Design of Windows as an External Building Feature in the Works of Loos and Le Corbusier", Architecture Research, (2019), Vol. 9 No.1, pp 16-22. doi: 10.5923/j.arch.20190901.03

[7] Ding, Z., Zhu, H., Wang, Y., and Ge, X., "Study and Analysis of Office Building Energy Consumption Performance in Severe Cold and Cold Region, China", Advances in Mechanical Engineering, (2017), Vol. 9 No.11, pp 1-21. doi: $0.1177 / 1687814017734110$

[8] Gillem, M. L., "Aesthetic Opportunities", (2016), Available at https://www.wbdg.org/resources/aesthetic-opportunities Accessed: 2020-05-03.

[9] Ichikawa, K., "Part 4: Postmodern Windows that Symbolize Liberation", Windows in Chinese Architecture, (2018), Available at https://madoken.jp/en/research/windowsin-chinese-architecture/3589/ Accessed: 2020-05-03.

[10] Lawson, B., Bassanino, M., Phiri, M., \& Worthington, J., "Intentions, practices and aspirations: Understanding learning in design”, Design Studies, (2003), Vol. 24 No. 4, pp 327-339. doi: https://doi.org/10.1016/S0142-694X(02)00066-2

[11] Lee E. S., Pang, X., McNeil, A., Hoffmann, S., Thanachareonkit, A., Li, Z., dkk., "Assessment of the Potential to Achieve very Low Energy Use in Public Buildings in China with Advanced Window and Shading Systems", Buildings, (2015), Vol. 5, pp 668-699. doi: 10.3390/buildings5020668

[12] Maduka, C., "Copycat, Eclecticism in Architecture", (2019), Available at https://www.thisdaylive.com/index.php/2019/08/06/copycat-eclecticism-in architecture/ Accessed: 2020-05-03.

[13] Noor Laily, M., Zalina, S., \& Nur Dalilah, D., "Building Envelope Retrofit: Enhancing Energy Performance in Existing Government Office Buildings in Malaysia", MU-IGBC 2018 - Energising Green Buildings, Mei (2018), Malaysia.

[14] Norberg-Schulz, C., Intentions in Architecture, April (1966), The MIT Press, Canada.

[15] Pemerintah Provinsi DKI Jakarta., Peraturan Gubernur Provinsi DKI Jakarta Nomor 38 Tahun 2012., (2012), Jakarta, Indonesia. 
[16] Shaeri, J., Habibi, A., Yaghoubi, M., \& Chokhachian , A., "The Optimum Windowto-Wall Ratio in Office Buildings for Hot - Humid, Hot - Dry, and Cold Climates in Iran", Environments, (2019), Vol. 6 No. 4, pp 1-16. doi: 10.3390/environments6040045

[17] Wa Ode, A., Antaryama, IGN., \& Ima, D., "ANALISA KONSERVASI ENERGI PADA BANGUNAN KANTOR PEMERINTAH DI SURABAYA", Proceedings of The 2nd ECO-Architecture Conference (EAC 2), (2015), Jawa Tengah, Indonesia

[18] Yan, D., Hong, T., Li, C., Zhang, Q., An, J., \& Hu, S., “A Thorough Assessment of China's Standard for Energy Consumption of Buildings", Energy and Buildings, (2017), Vol. 143, pp 114-128. doi: https://doi.org/10.1016/j.enbuild.2017.03.019 